喉 頭 外傷 の 2 例。

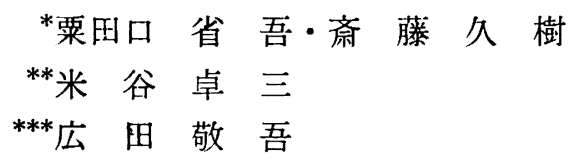

\title{
Two Cases of Laryngeal Injury
}

\author{
Shogo Awataguchi, Hisaki Saito
}

Dept. of Otorhinolaryngology, School of Medicine, Hirosaki University

Takuzo Yoneya

Dept. of Otorhinolaryngology, Odate City Hospital

Keigo Hirota

Dept. of Otorhinolaryngology, Aomori City Hospital

Two cases of laryngeal injury were reported. One case was a man aged 58, who had been nearly strangulated, when a vinyl rope hanging from a driving truck coiled around his neck accidentally. Operation was done under the emergency tracheotomy, and cervical contusion and rupture of hypopharyngeal wall with a moderate amount of bleeding were success fully treated. However, stenosis of the food passage remained persistently and gastrotomy was done. 2nd operation revealed partial fracture of the left inferior corn of thyroid cartilage and posterior dislocation of cricoid cartilage, which were completely repaired. He was discharged 87 days after the admission, with slight hoarseness.

Another case was a man aged 18 , who fell into a ditch with a motor cycle on full drive and was injured at the anterior portion of the neck. Five months after this injury, when he was transferred to our clinic, he was tracheotomized and had gastric fistula, not able to speak any word nor swallow any food. Reconstructive operation revealed the complete obstruction of larynx and esophagus, because epiglottis was almost completely torn off and adhered closely with the hypopharyngeal mucosa. After removal of epiglottis, the larynx was sutured with the base of the tongue including hyoid bone. He was discharged 338 days after the admission to our clinic, having good phonation but a slight difficulty in swallowing liquid food.

\section{I 緒言}

喉頭，上部気管，頸部食道の重篤なる損 傷 は，頚部に対し作用した鈍的な外力によつて起 るといわれている(1)2。原因として一番多いの は, 自動車衝突事故の際, 助手席に乗つた人が ダッシュボードに前頸部を打撲した場合にみら

*弘前大耳鼻科

**大館市立病院耳鼻科

$* * *$ 青森市民病院耳鼻科
れるもので, 最近, シートベルトの普及にとも ないこのタイプの外傷が増加しているといわれ ている。われわれはこの度, 対向車のビニール ロープによる1例および，バイク転倒事故によ る 1 例, 計 2 例の交通事故による喉頭外傷を治 療する機会を得たので報告する。

症例 1 58才, 男子, 商業

既往歴 特記すべきことなし

現病歴 昭和 47 年 11 月 5 日, 午後 4 時 50 分

頃, 自転車に乗つてカーブにさしかかった際, 
対向してきた小型トラックが引きずつていたビ ニールロープに上頸部を一巻きされて, 約 $2 \mathrm{~m}$ ひきずられた。口腔よりう出血, および, 軽度 の呼吸困難を訴え, 午後 6 時頃, 救急車にて大 館市立病院に入院した。

入院時局所々見 口腔よりの出血著明。上頸 部全周に亘り索状溝様擦過傷が見られ, 頸部, 顔面の腫脹著明。下咽頭および喉頭よりの出血 が高度で, 粘膜および軟部組織の挫隇片が吸引 された。

入院時全身所見および症状 腰部打撲傷を認 む。中等度の呼吸困難あり, 発声不能。意識は 明瞭でチアノーゼなし。胸, 腹部には異常を認 めなかつた。

入院時 X線写真所見 腰椎や頭蓋骨, 頸椎に 異常を認めなかつた。

\section{入院後の経過}

入院後, 直ちに中気管切開を施行したが，切 開部位には特に異常を認めず, 気管内で, 切開 口の上方部より血液が流下して来るのが認めら れた。気管切開後, 引き続いて下咽頭切開術を 行つた。

手術所見（図 $1 \mathrm{a}, \mathrm{b}$ )

予め行われていた気管切開口より気管内挿管 し，全麻下に手術を行つた。

舌骨の高さより左胸鎖乳突筋の前縁に沿つて 約 $7 \mathrm{~cm}$ の皮膚切開を行い, 更にこの皮切の上端 より䫟下部に沿って約 $6 \mathrm{~cm}$ 切開を加えた。皮下 組織を分離し, 広頸筋を切開すると, ジャクン ン氏三角部位に約 $50 \mathrm{ml}$ の凝血塊を認め, これ

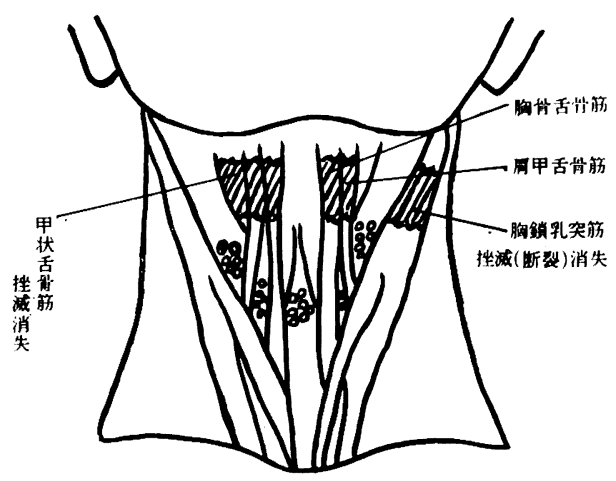

a
を除去。この部位にて左胸鎖乳突筋の上部, 胸 骨舌骨筋, 肩甲舌骨筋の断裂がみられた。この 甲状舌骨筋を一部切離し, 左下咽頭に達したと ころ, 咽頭側に貯留した凝血塊のため, 膨隆が みられ, 約 $5 \mathrm{~mm}$ 直径の穿孔がみられた。この 部位に約 $2 \mathrm{~cm}$ の縦切開を加え, 凝血除去後, 下 咽頭観察を行ったところ, 反対側の下咽頭損傷 が窥われたので, 前記頡下部の皮切を頸部正中 線まで，さらに約 $3 \mathrm{~cm}$ 延長した。右下咽頭より 喉頭部にかけての損傷は左側より著明であつ た。即ち, 胸骨舌骨筋, 肩甲舌骨筋, 上部喉頭 外筋 (甲状舌骨膜, 甲状舌骨筋) の挫隇消失, 右甲状軟骨上角切損, 下咽頭破裂（ほほ拇指頭 大）等が認められ,この部位の創全体からの出 血が激しかつた。

出血部位確認の上, 止血操作を施し, 可及的 に欠損部位を周囲組織で被覆しつつ, catgut に て両側下咽頭粘膜を縫合し, さらに, 頸部軟部 組織を縫合の上，皮膚切開創を 14 針縫合して手 術を終了した。

なお, 上頸部一周の索状痕に一致して皮下軟 部組織の挫滅損傷があり，凝血の貯留があつた が，出血は止まつており，それ以上に出血する 危険性のないことを確かめ, 術後, 外頸部より の圧迫を意図の上, 観察のみにて放置した。

終局, 上頸部に巻きついたビニールロープの 緊縛と,これの牽引の際に㗢いた左方より右方 向への外力の作用により生じた上頸部および喉 頭の挫傷と下咽頭破裂が考えられた。

手術終了後, ワングンスチーン氏胃栄養ゾン

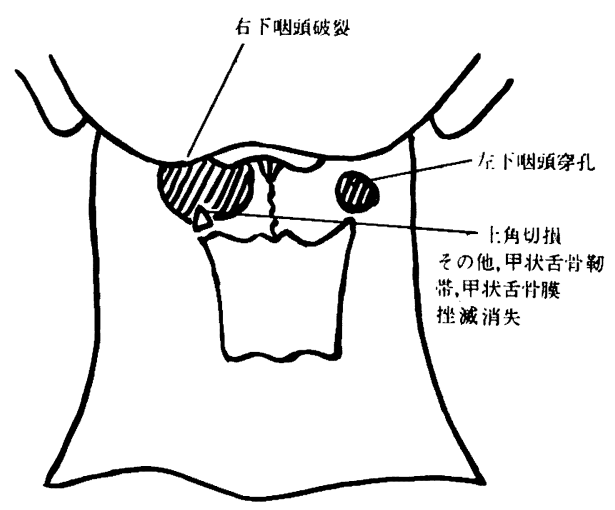

b

図1手術所見 (第1回目) 


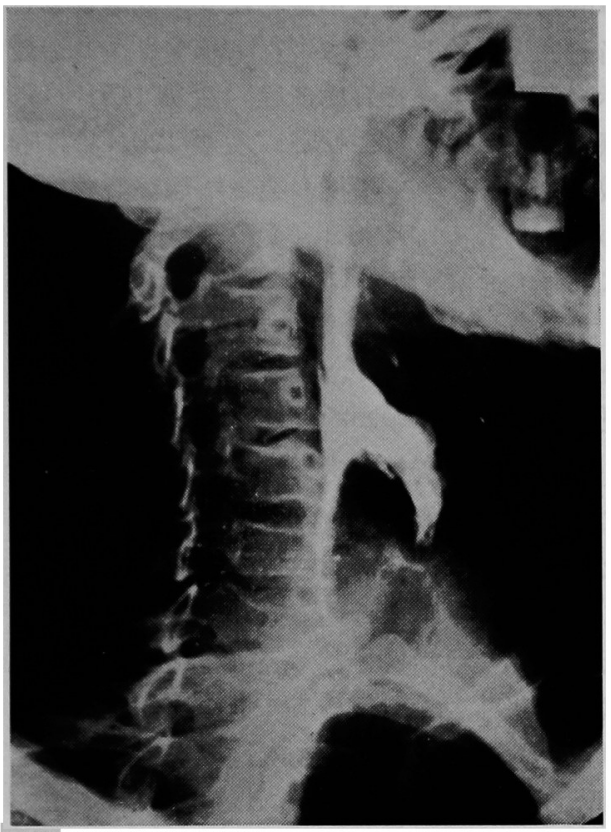

図 2 食道造影像（整腹手術前）

デの挿入を試みたが不可能であつた。食道鏡検 查を行つたところ，第一狭窄部位が異常に狭く なつており, 細巻き捲綿子がやつと通過する程 度であつた。輪状軟骨の食道側への転位が考え られた。しかし, 粘膜の損傷は認められなかつ た。なお, 数日後の食道造影像でも, 造影剂は ほとんど下咽頭に停滞した（図 2 ，食道造影 像)。

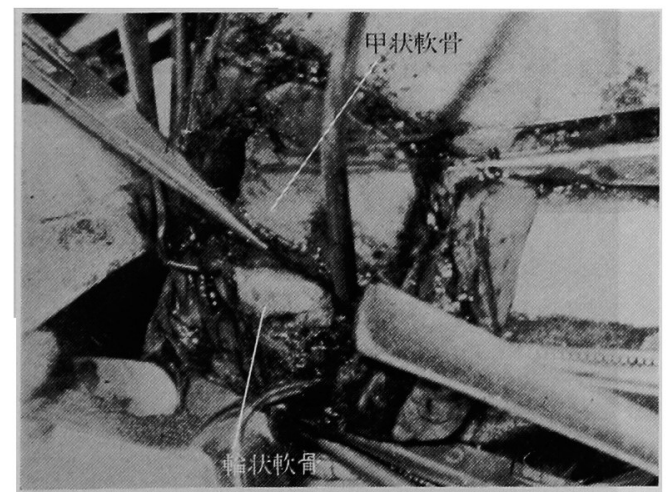

a
術後, 約10日間, $37.0^{\circ} \mathrm{C}$ 台の発熱が続いた が，化学療法によつて肺炎などの合併もなく経 過し, 気管カニューレ外管の空部を通じて自然 道よりの呼吸および発声も可能であった。この 閒, 胃瘦造設術を施行し, カテーテル栄養を行 つた。

11月28日（第24病日）, 食道狭窄治療のため, 輪状軟骨の整復手術を行つた。

手術所見 (図 $3 a, b)$

皮切は, 舌骨 ・ 甲状軟骨中間部に横切開を行 い, さらに前頸部正中線に沿って, 気管切開口 まで䋛切開を加えた。皮虔, 広頸筋を剝離し， さらに前喉頭筇層を左側のみ甲状軟骨拉よび輪 状軟骨前面より剝離した。続いて，喉頭截開術 を施行したところ，喉頭内部に特に損傷は認め なかつた。

輪状甲状鞄帯は引き延ばされて，両軟骨の間 隔は広くなつていた。輪状軟骨前部は下方に， 後部は後上方に移動し (図 3 a ), 輪状軟骨前 部抢上び甲状軟骨の左右両板の所々に小骨折が みられ, 輪状軟骨前面には刍裂が出来ていた (図 $3 \mathrm{~b}$ )。甲状軟骨左下端には骨折のあること が推定されたが，筋肉や鞄帯におおわれてお り，骨折線を明らかにすることは出来なかつ た。

転位した輪状軟骨を整復し，甲状軟骨板に縫 合固定し手術を終了した。

術後, 食道鏡検查で下咽頭・食道入口部の狭

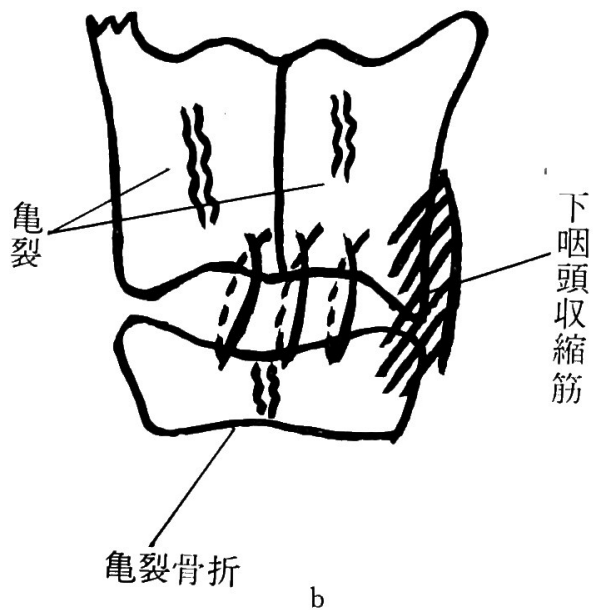

図3 手 術 所 見 (第 2 回目) 


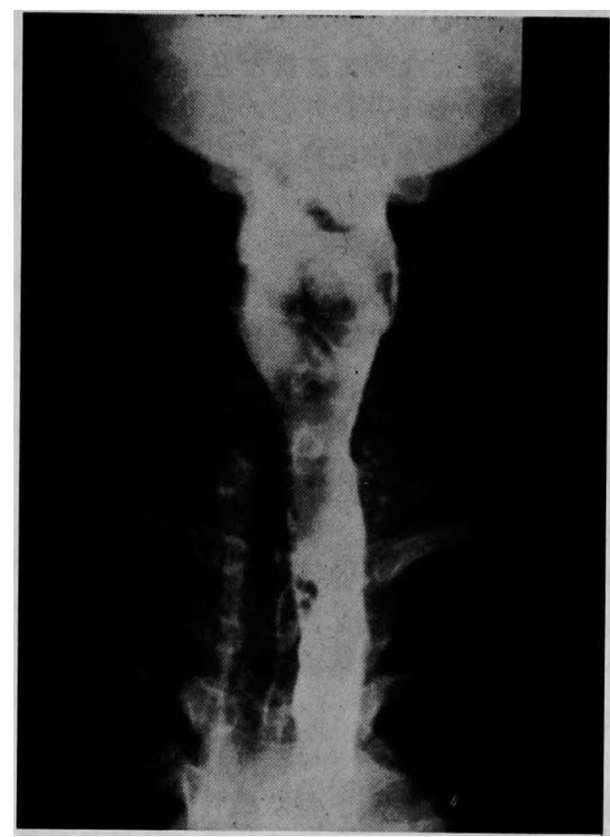

図 4 食道造影像（整復手術後）

窄は全くなくなつたことを確かめ, ワンゲンス チーン氏10号ゾンデを鼻腔より插入した。

術後の食道造影像にて狭窄の改善を確認した (図 4 )。

以後, 順調に経過し, 兴下機能も徐々に改善 したので, 昭和 48 年 1 月 31 日（第87病日, 第 2 回目の整復手術施行63日後）退院した。

現在は軽度嗄声を訴えるのみである。左披裂 軟骨の運動制限が認められることから，輪状披 裂関節の鉤縮が考えられる。

症例 2 18才，男子，大工

既往歴 14 才鎖骨々折

現病歴 昭和 47 年 7 月 25 日, 午前 5 時頃, ハ イク運転中転倒して側满に転落し, 前頸部に受 傷。受傷時の意識喪失のため, 状況の詳細は不 明。受傷直後より軽度の呼吸困難, 発声障害を 認め, 頸椎捻挫, 頸椎損傷ならびに咽喉頭部外 傷の診断にて, 某外科病院に入院。㫶下障害お よび誤嬹があるため, 受傷14日目に当科外来に 頼診され, 胃栄養ゾンデ(ワングンスティーン) 插入を示唆した。受傷26日目に某町立病院外科 に転院。呼吸困難が強くなり, 受傷30日目に気 管切開施行。胃栄養ゾンデ挿入不能となり, 経
口的には水分摂取も不能となり，受傷日32目に 当科に再受診し, 胃瘦 (ウィッツェル) 造設を 示唆した。翌々日冒瘦造設。受傷 115日目に青 森市民病院耳鼻科に転院。受傷 120日目に喉頭 截開術施行。嬩下不能, 発声不能が持続するた め, 昭和 47 年 12 月 26 日（受傷 155 日目）に当科 に転院。

入院時局所々見 入院時の間接喉頭鏡検査で は, 図 5 に示すように, 喉頭蓋と下咽頭後壁が 見えるのみで，喉頭内部は見られなかつた。

入院時全身所見 気管切開口招上び胃瘦以外 には, 四肢, 胸腹部その他に異常を認めなかつ た。

入院時 X線写真所見 喉頭側面の $\mathrm{X}$ 線写真で は，舌骨と甲状軟骨との著明な離断が見られ， 喉頭は甚だしく下降していた（図 6)c 気管切 開口を利用して行つた喉頭造影像では，両側下 咽頭の著明な変形および, 仮声帯の変形がみら れたが, 声帯の変形は軽度であつた（図 7 )。

入院後の経過

昭和 48 年 1 月 5 日, 手術用顕微鏡下に喉頭直 達鏡検査施行。直達鏡所見では，両側披裂部と

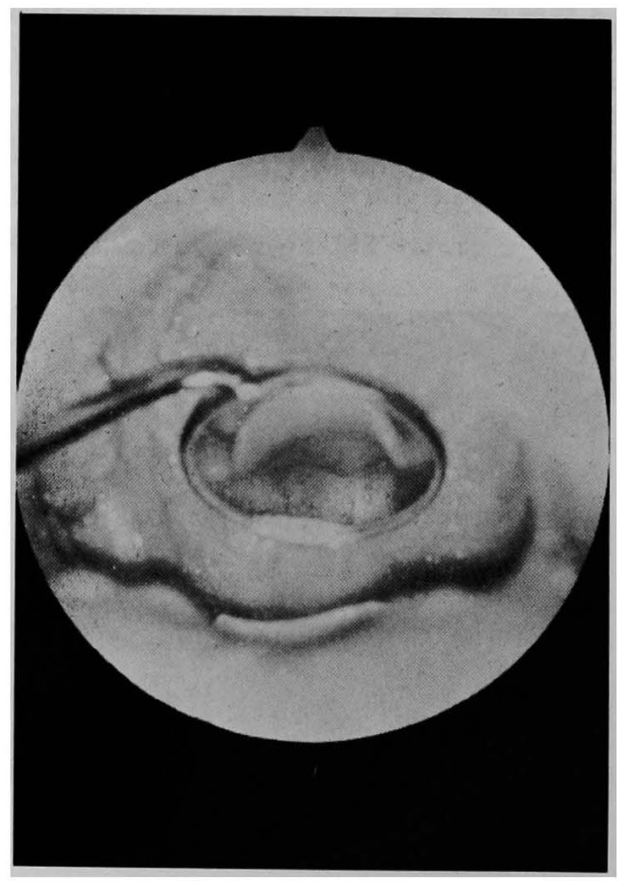

図 5 閒接喉頭鏡像 


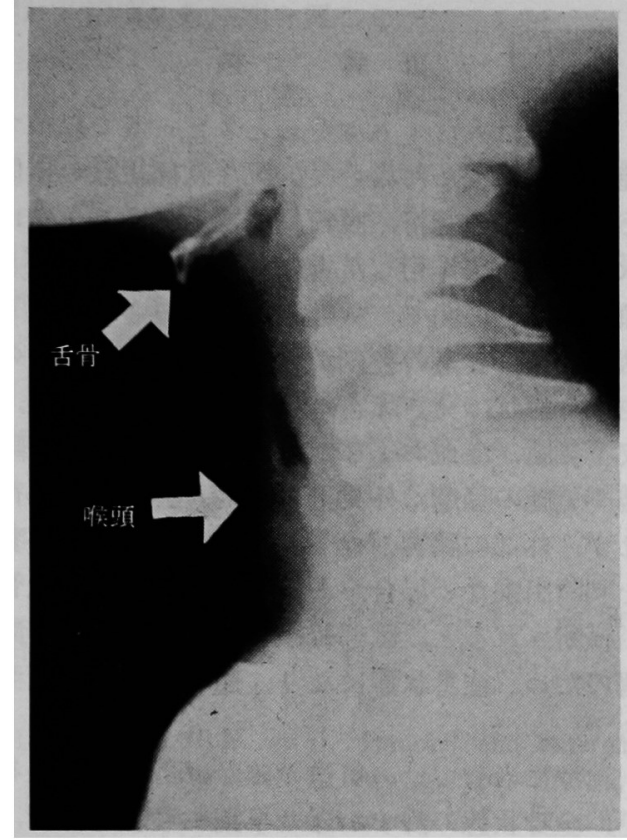

図 6 喉頭側面 X線像

思われる部位に著明な浮腫があり，一部，喉頭 内腔と思われる部位の粘膜も浮腫状で, 声帯は 見えなかつた。下咽頭後壁は, 肉芽様に腫脹し ていた。

1 月10日に，喉頭の整復手術を行つた。

手術所見 (図 $8 \mathrm{a}, \mathrm{b}$ )

喉頭蓋は瘏痕性に索状化し, 喉頭蓋茎部は喉 頭の固有の位置から全部引き出されて, 右外側 披裂壁および右外側下咽頭後壁と痒痕性に瘑着 し, 下咽頭腔で気道食道とも完全に閉塞されて いた。㾲痕性瘾着は非常に密であつたので，八

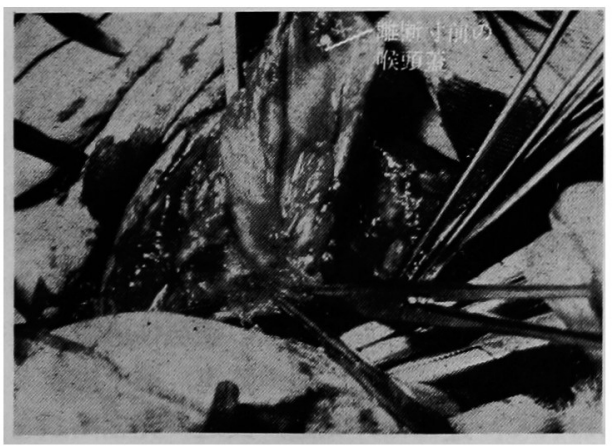

a

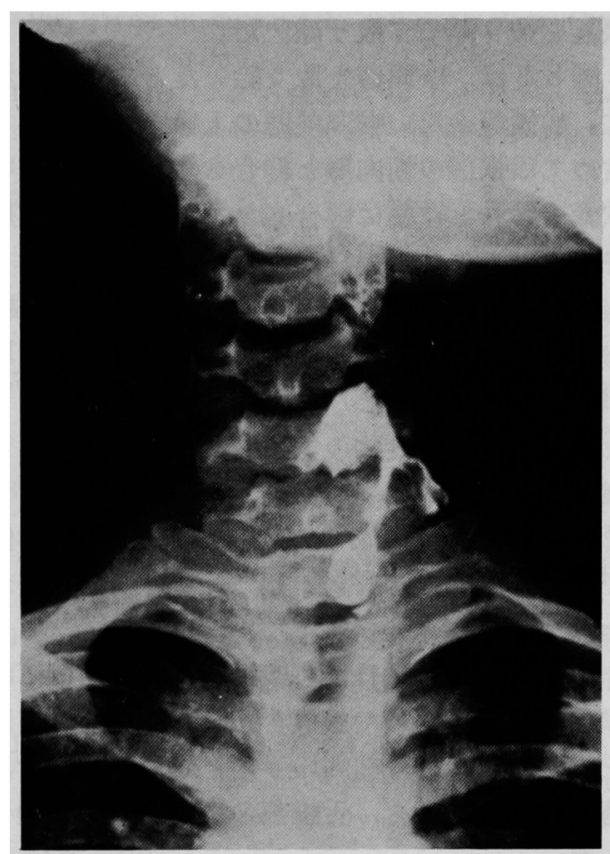

図7 喉 頭造影 像

下咽頭の変形が著明 両側仮声帯喉頭室も変形

サミとメスを用いて切り離した。喉頭蓋を下咽 頭後壁から切り離す際に, 下咽頭粘膜の一部が 頸椎の椎体から引き裂かれたので，カットグー トにて縫合した。図 8 a は, 喉頭蓋の瘾着を周 囲から切り離してつりあげたところを示す。喉 頭内部の粘膜は正常であつた。麻酔を浅くし， 刺激すると, 両側声帯のほぼ正常の運動が見ら れた。喉頭蓋茎部と甲状軟骨とは一部の甲状喉 頭蓋勒帯を残すのみにて離断していたので，喉

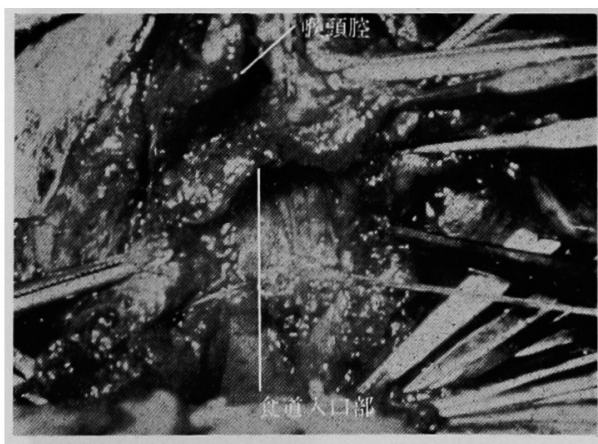

b

图8手術所見 
頭蓋を切り離して取り除いた。

図 $8 \mathrm{~b}$ は, 喉頭蓋を取り除いたところを示 す。喉頭蓋のない喉頭前庭の上縁を, 舌骨をも 含めて舌根部の筋肉層と縫合した。また, 甲状 軟骨と舌骨とは密に縫合した。軟部組織と皮膚 弁によつてこれらの縫合を被覆した。

その後, 数回に亘つて, 喉頭直達鏡下に喉頭 および食道入口部に操作を加えた後, 経口摄取 扝よび発声が可能となつたが，気管カニューレ を抜去すると, 食物の気道内への誤飲がおこつ た。図 9 は, 術後, 造影剂としてハイトラスト を使用した，食道および，喉頭・気管造影像 で，舌骨と喉頭とが虧断しているのが認められ た

昭和 48 年 9 月 10 日に再手術を行い, 右側下咽 頭後壁に認められた瘚痕を切除し, 食道入口部 を桩張した後に, 前回の手術と同じく, 舌骨, 遺残喉頭の上縁を, 舌根部の筋肉層と密に縫合 した。

昭和48年10月15日より経口的に普通食摂取可 能となり, 同年11月12日より気管切開口を閉鎖 しても呼吸困難, 䛊飲を認めず, 同年11月30日 （受傷後493日目で, 当科入院後338日目）に退 院した。

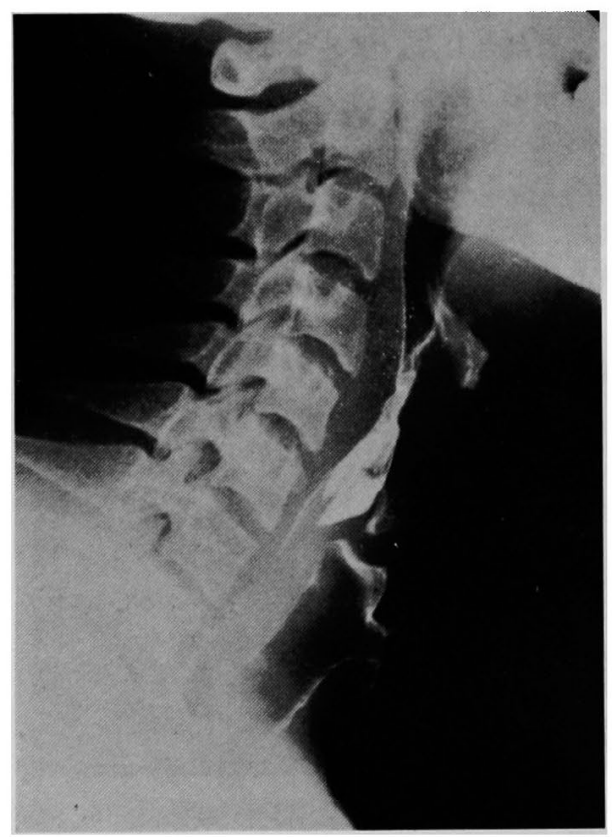

図 9 食道および喉頭造影像

\section{III 考按}

頸部に巨大なエネルギーとスピードで以つて 鈍的な力が及んだ場合, 広汎な軟部組織の損傷 と喉頭軟骨の骨折, 脱臼, 転位が生ずる。殊に 水平に外力が作用した場合には, 甲状軟骨板と 頸椎前面との間で, 軟部組織が圧迫されて, 下 咽頭や頸部食道の裂創が起り得る。そのときの 主なる症状は発声障害, 嬹下困難, 呼吸困難, 皮下気腫, 溢血扝よび出血等であるが, 発声障 害や気腫の程度は外見上の変化と必ずしも平行 せず, 外部の障害の程度から内部諸器官の病変 を判断出来ない場合がある2。 また，上部気管 が横断されると, 軟部組織や血液による気管閉 塞のため, 窒息状態になり，速やかに死に至 る $^{475}$ 。

治療に当つては, 気道の確保は当然である が, 全身状態の許すかぎり早期に喉頭, 気管, 食道の再建を計ることが肝要である(6)7>8>9)。危 急性が強くなればなる程, 再建の時期を逸し易 く, 広汎な創傷の感染, 化膿, 組織の脱落, 症 痕性収縮を来たし, 喉頭や食道の機能に障害を 遺す結果となる。

症例 1 は, 頸部を絞扼された状態に類似した 機序で受傷し, 莖部の軟部組織の挫滅, 輪状軟 骨の骨折，転位を来した例であつたが，喉頭内 部や気管の損傷を免れたため, 受傷部位よりの 多量出血および来院までのかなりの時間的経過 にもかかわらず, 気道閉塞を避け得たものと考 えられる。また, 下咽頭破裂を合併したもの の，食道損傷を起さなかつたことは幸運であつ たと考えられる。

症例 2 は, 受傷当時の状況から考えて, 症例 1 よりも軟部組織の損傷の程度は激しかつたと 考えられ，喉頭蓋は離断寸前で，遊離した下部 および前壁は，下咽頭後壁および右側壁と瘢痕 性に癒着しており, 舌骨と喉頭とは離断してい た。これらの手術時の所見からみれば, 受傷後 日時を経るに従つて, 組織の瘷痕性瘾着が進行 し, 次第に呼吸困難, 発声障害, 㫶下障害があ らわれて, 遂には, 気道, 食道の完全閉鎖を来 すに至つたと考えられる。この例においては, 種々の事情により喉頭の再建術を施行するのが 
遅れ，治療に長期間を要した。

\section{IV 結 語}

自転車に乗つて通行中に，対向してきた小型 トラックからたれさがつていたビニールロープ が頸部に巻きついて引きずられ，頸部挫傷，下 咽頭破裂, 輪状軟骨々折と転位, およびそれに よる食道狭窄の合併をみた58才男子の症例と， バイク運転中転倒して側溝に転落し，前頸部に 受傷して, 喉頭の脱臼, 喉頭狭窄, 食道狭窄, および喉頭蓋離断を来した18才男子の症例の 2 例の喉頭外傷患者の治験例を報告した。

本論文の要旨は第 157 回東北地方会例会, 第25回 日本気管食道科学会総会において発表した。

\section{文献}

1) Holinger, P.H. et al. : Internal and external trauma to the larynx. Laryngoscope. $78: 944-$ 954, 1968.

2 ) Ogura, J.H. et al. : Functional restitution of traumatic stenosis of tho larynx ana pharynx. Laryngoscope. 74; 1081-1110, 1964.

3 ) Nahm, A.M. et al. : Biodynamics of injury to the larynx in automotile collisions. Ann. Otol. 76 ; 781-785, 1967.

4) Chandler, J.R. : Avulsion of the larynx and pha rynx as the result of a water ski rope injury. Archiv. cf Otolaryng. $96 ; 365-367,1972$.

5 ) Butler, R.M. et al. : The padded dash syndrome: Blunt trauma to the larynx and trachea. Laryngoscope. 78 ; 1172-1182, 1968.

6 ) Priest, R.E. et al. : Laryngotracheal injuries. Ann. Otol. 76 ; 786-792, 1967.

7 ) Fitz-Hugh, G.S. et al. : Injuries of the larynx and cervical trauma. Ann. Otol., $71 ; 419-442$, 1962.

8 ) Harris, H.H. : Symposium on trauma in otolaryngology. IV. Management of injuries to the larynx and trachea. Laryngoscope. 82 ; 19241929, 1972.

9 ) 沢木修二：喉頭外傷。耳喉, 41；819-827, 1969.

10）武本欣也：喉頭頸部気管の外傷による慢性狭窄 の治療体系の確立。日耳鼻。75；112-136, 1972.

11) Harris, H.H. et al. : Acute injuries of the larynx and trachea in 49 patients. (Otservations over a 15-year period.) Laryngoscope. 80 ; 13761384, 1970.

12) Alonso, W.A. et al. : Minibikes, a new facfor in laryngotracheal trauma. Ann. Otol., 82 ; 800-804, 1973. 